\title{
Molecular phylogeny of Speiropsis pedatospora
}

\author{
Pratibha $\mathrm{J}^{1}$, Bhat $\mathrm{DJ}^{2}$ and Prabhugaonkar $\mathrm{A}^{3}$ \\ ${ }^{1}$ Department of Botany, Goa University, Goa 403 206, India. Email: jalmipratibha@ rediffmail.com \\ ${ }^{2}$ 128/1-J, Azad Co-op Housing Society, Curca, Goa Velha 403 108, India. Email:bhatdj@gmail.com \\ ${ }^{3}$ Botanical Survey of India, Eastern Regional Centre, Shillong 79300, India.
}

Pratibha J, Bhat DJ, Prabhugaonkar A 2016 - Molecular phylogeny of Speiropsis pedatospora. Mycosphere 7 (5), 679-686, Doi 10.5943/mycosphere/7/5/12

\begin{abstract}
Speiropsis pedatospora, an aero-aquatic fungus, was isolated from submerged plant litter in freshwater streams from India. Based on analysis of combined ITS and LSU sequence data, the species was positioned in the family Weisneriomycetaceae, as a sister group to Tubeufiales in the Dothideomycetes, instead of its current placement in the order Jahnulales. Speiropsis pedatospora, is the type species of the genus Speiropsis, is morphologically characterised by macronematous, mononematous, erect, branched conidiophores, polyblastic, denticulate, discrete conidiogeneous cells and long catenate conidia linearly joined by narrow, small isthmi. All asexual morph members of Weisneriomycetaceae with isthmospores are morphologically similar to the genus Speiropsis.
\end{abstract}

Key words - aquatic fungi - Dothideomycetes - fungal diversity - phylogeny of asexual fungi Western Ghats

\section{Introduction}

A natural classification of asexual morph taxa in families, orders and classes of Ascomycota and Basidiomycota, are presently being undertaken, by analysing molecular sequence data along with morphology, in order to provide a natural classification. Asexual morph are also being linked to their sexual genera by molecular data and major revisions of the ascomycota are taking place (Hyde et al. 2011, Wijayawardene et al. 2014). Our continued work on taxonomy of asexual fungi (Pratibha \& Prabhugaonkar 2015a, b, Pratibha et al. 2014a, b) yielded a rare collection of the asexual genus Speiropsis, and the phylogenetic study of this taxon is the subject of this paper.

The genus Speiropsis Tubaki is typified by Speiropsis pedatospora Tubaki (Tubaki 1958). There are eight species listed in the genus (Index fungorum 2016). Speiropsis species are characterized by erect, simple, straight, septate, mostly mononematous conidiophores with discrete, denticulate, polyblastic conidiogenous cells and catenate conidia in branched or unbranched chains connected by narrow isthmi (Ellis, 1976. Speiropsis pedatospora has often been collected from terrestrial leaf litter and submerged plant litter (Ellis, 1976, Barbosa \& Gusmao 2005, Patil et al. 2014, Pratibha et al. 2012). Based on phylogenetic analysis of ITS rDNA of cultures obtained from BIOTEC Culture Collection (BCC, Thailand) and the Centraalbureau voor Schimmelcultures (CBS, Netherlands), Prihatini et al. (2008) have shown that Speiropsis pedatospora belonged to order Jahnulales and clustered with Jahnula species. However these cultures are no longer available in the catalogues of those culture collections. Based on Prihatini et al. (2008), the genus Speiropsis with all its accepted species have been treated in the order Jahnulales (Shearer et al. 2009, Suetrong et al. 2011, Hyde et al. 2013, Wijayawardene et al. 2014). 
In the current study, Speiropsis pedatospora was isolated from leaf litter collected from a freshwater stream of Western Ghats, Goa, India and subsequently cultured using single spore isolation (Chomnunti et al. 2014). In our phylogenetic study, the taxon was observed to be related to family Weisneriomycetaceae, instead of its present placement in Jahnulales. Weisneriomycetaceae (Suetrong et al. 2014), typified by the genus Weisneriomyces Koord. is morphologically similar to the genus Speiropsis in having polyblastic conidiogenous cells and catenate conidia in chains connected by narrow isthmi, but differs by sporodochial or synnamatous conidiomata and unbranched or rarely branched conidial chains.

\section{Materials \& Methods}

\section{Collection and culturing}

Freshly aquatic litter samples were taken to the laboratory in sealed polythene bags. The sample was observed under stereomicroscope and fungal material picked with a fine-tipped needle and mounted on a slide containing a drop of lactophenol solution. This was examined under a light microscope for morphological details.

The culture of Speiropsis pedatospora was obtained by single spore isolation (Chomnunti et al. 2014). Colonies developing from individual conidia were aseptically transferred to new plates (Bhat 2010). DNA isolation and sequencing work was outsourced to Rajiv Gandhi Centre for Biotechnology, Thiruvananthpuram, India. Facesoffungi numbers are added (Jayasiri et al. 2015).

\section{DNA isolation and PCR Analysis}

Fresh fungal mycelia $(20 \mathrm{mg})$, scraped from the growing culture incubated at $28^{\circ} \mathrm{C}$ for 7 days. DNA isolation and PCR Analysis was done according to Prabhugaonkar \& Bhat (2011). The 5.8S nuclear ribosomal gene with the two flanking internal transcribed spacers (ITS) and $28 \mathrm{~S}$ nrDNA sequence (LSU) genes were amplified and sequenced using the primer pairs ITS-1F + ITS4R (White et al. 1990) and LR5 + LROR (Crous et al. 2009) respectively. The sequence quality was checked using Sequence Scanner Software v.1 (Applied Biosystems). Sequence alignment and required editing of the obtained sequences were carried out using Geneious Pro v5.1 (Drummond et al. 2010).

\section{Sequence alignment and phylogenetic analysis}

The sequences were blasted in GenBank with Blastn. ITS and LSU data to obtain related taxa. Taxa were also chosen based on recent publications on Tubeufiales (Boonmee et al. 2011, 2014). The sequence data was assembled for each taxon. The combined data matrix was aligned using MAFFTv.7 (http://mafft.cbrc.jp/alignment/server/index.html) and manually adjusted using MEGA 6.06 to allow maximum alignment and maximum sequence similarity. Phylogenetic analysis was conducted using maximum likelihood (ML) in MEGA6.06 (Kumar et al. 2008) with 1,000 bootstrap replicates. The most suitable substitution model Kimura-2-parameter model with Gamma distributed with Invariant sites $(\mathrm{G}+\mathrm{I})$ was selected by using MEGA6.06. Gaps were treated as a pair-wise deletion and tree was viewed with MEGA6.06. Newly generated ITS and LSU sequences used are deposited in GenBank.

\section{Results}

\section{Phylogenetic analyses}

Forty-two taxa are included in the phylogenetic analysis (Table 1, Fig. 1). The result of phylogenetic analysis showed that Speiropsis pedatospora has close affinities with Tubeufiales, Dothideomycetes. A dataset of two families of Tubeufiales was assembled. Pleospora herbarum from Pleosporaceae was selected as the outgroup taxon. Upon analysis of sequence data, it was observed that Speiropsis pedatospora forms a separate basal group to family related to Weisneriomycetaceae and Tubeufiaceae in the Tubeufiales. 


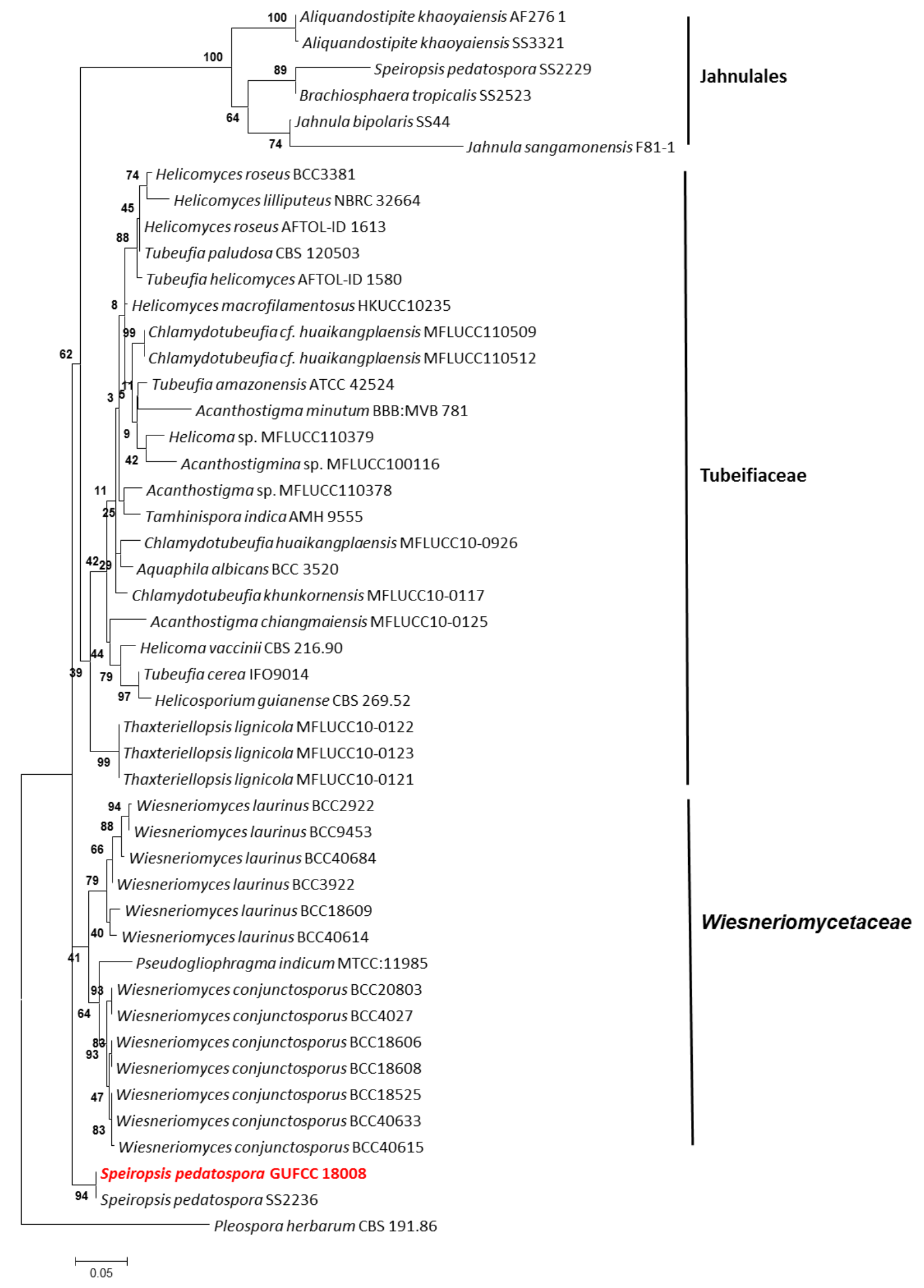

Fig. 1 - Maximum likelihood (ML) tree inferred from, ITS and LSU showing the relationship of Speiropsis pedatospora with Wiesneriomycetaceae. The species dealt in the present study is in red. 


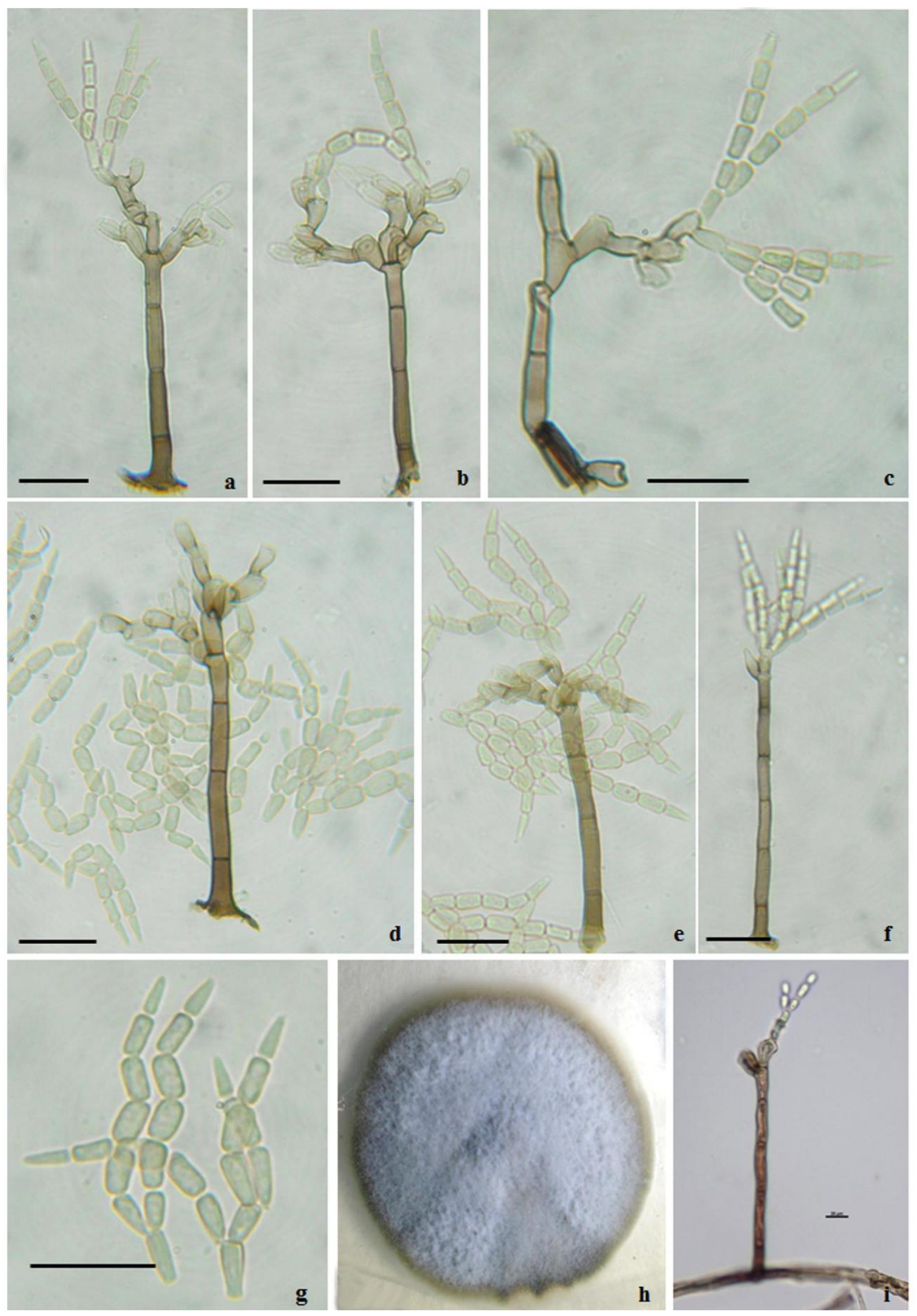

Fig. 2 - Speiropsis pedatospora a-f, conidiophore with conidia. g. conidial chains. h. culture. i. conidiogenesis in culture. Scale bars $=10 \mu \mathrm{m}$. 
Table1 Sequence data used in combined ITS and LSU analyses. Newly deposited sequences are in bold

\begin{tabular}{|c|c|c|c|}
\hline Taxon & Accession no. & ITS & LSU \\
\hline Acanthostigma chiangmaiensis & MFLUCC10-0125 & JN865209 & JN865197 \\
\hline Acanthostigma minutum & BBB:MVB 781 & - & JN127360 \\
\hline Acanthostigma sp. & MFLUCC 110378 & KF301523 & KF301531 \\
\hline Acanthostigmina sp. & MFLUCC100116 & KF301526 & KF301534 \\
\hline Aliquandostipite khaoyaiensis & AF276_1 & JN942357 & JN673028 \\
\hline Aliquandostipite khaoyaiensis & SS3321 & JN819278 & EF175650 \\
\hline Aquaphilaalbicans & BCC 3520 & DQ341098 & DQ341102 \\
\hline Brachiosphaera tropicalis & SS2523 & FJ887923 & JN819284 \\
\hline Chlamydotubeufia cf. huaikangplaensis & MFLUCC 110509 & KF301527 & KF301535 \\
\hline Chlamydotubeufia cf. huaikangplaensis & MFLUCC 110512 & KF301528 & KF301536 \\
\hline Chlamydotubeufia huaikangplaensis & MFLUCC10-0926 & JN865210 & JN865198 \\
\hline Chlamydotubeufia khunkornensis & MFLUCC10-0117 & JN865201 & JN865189 \\
\hline Helicoma sp. & MFLUCC 110379 & KF301524 & KF301532 \\
\hline Helicoma vaccinii & CBS 216.90 & AY916486 & AY856879 \\
\hline Helicomyces lilliputeus & NBRC 32664 & AY916483 & AY856899 \\
\hline Helicomyces macrofilamentosus & HKUCC10235 & - & AY849942 \\
\hline Helicomyces roseus & BCC 3381 & - & AY787932 \\
\hline Helicomyces roseus & AFTOL-ID 1613 & - & DQ678083 \\
\hline Helicosporium guianense & CBS 269.52 & AY916487 & AY856893 \\
\hline Jahnula bipolaris & SS44 & JN819281 & EF175658 \\
\hline Jahnula sangamonensis & F81-1 & JN942351 & EF175663 \\
\hline Pleosporaherbarum & CBS 191.86 & KC584239 & DQ247804 \\
\hline Pseudogliophragma indicum & MTCC:11985 & KM052850 & KM052851 \\
\hline Speiropsis pedatospora & SS2229 & FJ887926 & JN819285 \\
\hline Speiropsis pedatospora & GUFCC 18008 & KU563769 & KU563770 \\
\hline Speiropsis pedatospora & SS2236 & FJ887927 & \\
\hline Tamhinisporaindica & AMH 9555 & KC469282 & KC469283 \\
\hline Thaxteriellopsis lignicola & MFLUCC10-0122 & JN865206 & JN865194 \\
\hline Thaxteriellopsis lignicola & MFLUCC10-0123 & JN865207 & JN865195 \\
\hline Thaxteriellopsis lignicola & MFLUCC10-0121 & JN865205 & JN865193 \\
\hline Tubeufia amazonensis & ATCC 42524 & AY916458 & AY787938 \\
\hline Tubeufiacerea & IFO9014 & - & AY849964 \\
\hline Tubeufia helicomyces & AFTOL-ID 1580 & - & DQ767654 \\
\hline Tubeufia paludosa & CBS 120503 & - & GU301877 \\
\hline Wiesneriomyces conjunctosporus & BCC20803 & - & KJ425453 \\
\hline Wiesneriomyces conjunctosporus & BCC4027 & - & KJ425449 \\
\hline Wiesneriomyces conjunctosporus & BCC18606 & - & KJ425451 \\
\hline Wiesneriomyces conjunctosporus & BCC18608 & - & KJ425452 \\
\hline Wiesneriomyces conjunctosporus & BCC 18525 & - & KJ425450 \\
\hline Wiesneriomyces conjunctosporus & BCC40633 & - & KJ425455 \\
\hline Wiesneriomyces conjunctosporus & BCC40615 & - & KJ425454 \\
\hline Wiesneriomyces laurinus & BCC2922 & - & KJ425456 \\
\hline Wiesneriomyces laurinus & ВCС 9453 & - & KJ425458 \\
\hline Wiesneriomyces laurinus & ВCC40684 & - & KJ425461 \\
\hline Wiesneriomyces laurinus & ВCС 3922 & - & KJ425457 \\
\hline Wiesneriomyces laurinus & ВCC18609 & - & KJ425459 \\
\hline Wiesneriomyces laurinus & BCC40614 & - & KJ425460 \\
\hline
\end{tabular}

\section{Taxonomy}

Speiropsis pedatospora Tubaki, J. Hattori Bot. Lab. 20: 171. 1958

Facesoffungi number: FoF 02652

Colonies on natural substrate effuse, white, flexuous. Conidiophores macronematous, mononematous, simple, straight or flexuous, solitary, smooth, brown, branched at the tip, 73-120 $\times$ 4-6.5 $\mu \mathrm{m}$. Conidiogenous cells polyblastic, proliferating, sympodial, discrete, smooth, light brown, 8-12.5 × 4-8.5 $\mu \mathrm{m}$. Conidia $6-12.5 \times 2.5-5.5 \mu \mathrm{m}$, catenate, with 4-8 linearly connected by narrow 
isthmi, cylindrical to cuneiform, smooth, pale to mid-brown, often forming branched chains $65-80$ $\mu \mathrm{m}$ long.

Colonies on MEA greyish green, planar, irregular in outline, filamentous, with a black reverse, attaining $2.8 \mathrm{~cm}$ diameter after 7 days.

Known distribution - widespread in tropical and subtropical regions.

Material examined - INDIA, Goa, Canacona, Cotigao, on an unidentified fallen leaf in a freshwater stream, 30 Oct 2012, Ashish P., (herbarium no. LF-28) - living culture GUFCC 18008; INDIA, Goa, Ponda, Bondla, on an unidentified fallen leaf in freshwater stream, 11 Oct 2015, (collector) Pratibha J.; INDIA, Meghalaya, Jowai, Tyrshi falls, on an unidentified dry leaf in freshwater stream, 13 Jul 2016, (collector) Ashish P. (herbarium no. AVP-102)

\section{Discussion}

Suetrong et al. (2014) introduced the family Weisneriomycetaceae as sister to Tubeufiaceae in the Dothideomycetes to accommodate asexual isthmosporous fungus Wiesneriomyces. The family Weisneriomycetaceae without any known sexual state is originally characterised by sporodochial setose conidiomata, with setae arising from basal pseudoparenchymatous stalk or mycelium immersed in the substrata. The conidiophores are macronematous, septate and branched. The conidiogenous cells are holoblastic, discrete, determinate, terminate, clavate to cylindrical. The conidia are hyaline, non-septate; the conidium at each end of a chain is tapered, with intermediate ones more or less cylindrical, formed in uniseriate, acropetal chains and connected by narrow isthmi (=phragmoconidia) (Suetrong et al. 2014). Branching of conidial chains was rarely observed. Pseudogliophragma Phadke \& V.G. Rao, added as second genus in the Weisneriomycetaceae by Pratibha et al 2014, differs from Wiesneriomyces by synnematous conidiomata and dry, swollen, much shorter conidia. The genus Speiropsis is different from Pseudogliophragma and Wiesneriomyces in having erect, simple, straight, mostly mononematous conidiophores and catenate conidia in mostly branched chains. Sequence data analysis showed that Speiropsis pedatospora forms a separate basal group to family Weisneriomycetaceae and Tubeufiaceae in the Tueufiales. This observation is different from current placement of the genus in the Jahanulales (Prihatini et al. 2008, Shearer et al. 2009, Suetrong et al. 2011, Wijayawardene et al. 2014). It was observed that this classification was adopted based on single-gene phylogenetic study by Prihatini et al. 2008. In our analysis of sequence data of Prihatini et al. 2008, it was observed that one of the sequences, Speiropsis pedatospora SS2236, grouped well with our collection placed in Weisneriomycetaceae, whereas the second sequence deposited by authors (Speiropsis pedatospora SS2229) clustered in Jahnulales. In this study, we propose correct phylogenetic placement for Speiropsis based on study of ITS and LSU regions generated from our collection. This placement is further supported by morphological similarity of genus Speiropsis to the family Weisneriomycetaceae.

As discussed by Pratibha et al 2014, in the absence of adequate molecular data on morphologically similar asexual genera such as Abgliophragma R.Y. Roy \& S. Gujarati, Gliophragma Subram. \& B.C. Lodha and Phalangispora Nawawi \& Webster, further collections and morpho-molecular studies are necessary for more stable generic concepts in Weisneriomycetaceae.

\section{Acknowledgements}

Thanks are due to the University Grants Commission, New Delhi, for a post-doctoral research grant support to PJ. Prof. M.K. Janarthanam and Head of Department of Botany, Goa University, is thanked for supporting this work. AP acknowledges Director, Botanical survey of India and Dr. A. A. Mao, Head, Botanical Survey of India, Eastern Regional Centre, Shillong, India for support.

\section{References}

Barbosa FF, Gusmao LFP. 2005 - Two Speiropsis species (Anamorphic fungi-Hyphomycetes) from Bahia state, Brasil. Acta Bot Bras 19, 515-518. 
Bhat DJ. 2010 - Fascinating Microfungi (Hyphomycetes) of Western Ghats, India. Broadway Publishers, Panaji, Goa, 219 pp.

Boonmee S, Zhang Y,Chomnunti P, Chukeatirote E, Tsui CKM, Bahkali AH \& Hyde KD. 2011 Revision of lignicolous Tubeufiaceae based on morphological re-examination and phylogenetic analysis. Fungal Diversity 51, 63-102

Boonmee S, Rossman AY, Liu JK, Li WJ, Dai DQ, Bhat DJ, Jones EBG, McKenzie EHC, Xu JC, Hyde KD. 2014 -Tubeufiales, ord. nov., integrating sexual and asexual generic names. Fungal Diversity 68, 239-298.

Chomnunti P, Hongsanan S, Aguirre-Hudson B, Tian Q, Peršoh D, Dhami MK, Hyde KD. 2014 The sooty moulds. Fungal Diversity 66, 1-36

Crous PW, Braun U, Wingfield MJ, Wood AR, Shin HD, Summerell BA, Alfenas AC, Cumagun CJR, Groenewald JZ. 2009 - Phylogeny and taxonomy of obscure genera of microfungi. Persoonia 22, 139-161. doi:10.3767/003158509X461701

Drummond AJ, Ashton B, Buxton S, Cheung M, Cooper A, Heled J, Kearse M, Moir R, StonesHavas S, Sturrock S, Thierer T, Wilson A. 2010 - Geneious v. 5.1, Available from: http://www.geneious.com/ (accessed 22 June 2015)

Ellis MB 1976 - More dematiaceous hyphomycetes. Commonwealth Mycological Institute, Kew, $507 \mathrm{pp}$.

http://mafft.cbrc.jp/alignment/server/index.html

Hyde KD, Jones EBG, Liu JK, Ariyawansa H, Boehm E, Boonmee S, Braun U, Chomnunti P, Crous PW, Dai DQ, Diederich P, Dissanayake A, Doilom M, Doveri F, Hongsanan S, Jayawardena R, Lawrey JD, Li YM, Liu YX, Lücking R, Monkai J, Muggia L, Nelsen MP,

Hyde KD, McKenzie EHC, KoKo TW. 2011 - Towards incorporating anamorphic fungi in a natural classification - checklist and notes for 2010. Mycosphere 2(1), 1-88.

Jayasiri SC, Hyde KD, Abd-Elsalam KA, Abdel-Wahab MA, Ariyawansa HA, Bhat J, Buyck B, Dai YC, Ertz D, Hidayat I, Jeewon R, Jones EBG, Karunarathna SC, Kirk P, Lei C, Liu JK, Maharachchikumbura SSN, McKenzie E, Ghobad-Nejhad M, Nilsson H, Pang KL, Phookamsak R, Rollins AW, Romero AI, Stephenson S, Suetrong S, Tsui CKM, Vizzini A, Wen TC, De Silva NI, Promputtha I, Kang JC 2015 - The faces of fungi database: fungal names linked with morphology, molecular and human attributes. Fungal Diversity 74, 3-18. http://dx.doi.org/10.1007/s13225-015-0351-8

KM, Wijayawardene NN, Wikee S, Wu HX, Zhang Y, Aguirre-hudson B, Alias SA, Aptroot A, Bahkali AH, Bezerra JL, Bhat DJ, Camporesi E, Chukeatirote E, Gueidan C, Hawksworth DL, Hirayama K, Hoog SD, Kang JC, Knudsen K, Li WJ, Li XH, Liu ZY, Mapook A, McKenzie EHC, Miller AN, Mortimer PE, Phillips AJL, Raja HA, Scheuer C,

Kumar S, Nei M, Dudley J, Tamura K. 2008 - MEGA: Abiologist-centric software for evolutionary analysis of DNA and protein sequences. Briefings in Bioinformatics 9, 299-306.

Pang KL, Phookamsak R, Senanayake I, Shearer CA, Suetrong S, Tanaka K, Thambugala

Patil DK, Patil KB, Borse KN, Borse BD. 2014 - Freshwater hyphomycetes from Madhya Pradesh (India). International science journal. 1 (3), 8-12

Prabhugaonkar A, Bhat DJ. 2011 - New record of Megacapitula villosa and Paradictyoarthrinium diffractum from India. Mycosphere 2, 463-467.

Pratibha J, Mel'nik VA, Bhat DJ, Nguyen HDT, Seifert KA. 2014a - Taxonomy and phylogeny of Pseudogliophragma indica and its synonym Ramaraomyces corticola, a synnematous hyphomycete from south east Asia. Mycoscience 56 (4), 387-395. doi:10.1016/j.myc.2014.12.002

Pratibha J, Prabhugaonkar A, Bhat DJ, Hyde KD. 2014b - Phylogenetic placement of Bahusandhika, Cancellidium and Pseudoepicoccum (asexual Ascomycota). Phytotaxa. 176 (1), 068 - 080. doi:10.11646/phytotaxa.176.1.9

Pratibha J, Prabhugaonkar A. 2015a - Multi-gene phylogeny of Pithomyces with the sexual morph of P. flavus Berk. \& Broome. Phytotaxa 218 (1), 84-90. doi:10.11646/phytotaxa.218.1.7 
Pratibha J, Prabhugaonkar A. 2015b - New record of Thysanorea papuana from India. Mycosphere 6(4), 463-467. doi:10.5943/mycosphere/6/4/9

Pratibha J, Raghukumar S, DJ Bhat. 2012 - Diversity of litter degrading microfungi from the forests of Western Ghats, India. In: Biodiversity and Taxonomy. Edited by A. Biju Kumar, M.P. Nayar, R.V. Varma and C.K. Peethambaran.Narendra Publishing House. Pg. 195-210.

Prihatini R, Boonyuen N, Sivichai S. 2008 - Phylogenetic evidence that two submerged-habitat fungal species, Speiropsis pedatospora and Xylomyces chlamydosporus belong to the order Jahnulales Incertae Sedis Dothideomycetes. Microbiol Indonesia 2, 136-140

Schumm F, Taylor JE, Tian Q, Tibpromma S, Wanasinghe DN, Wang Y, Xu JC, Yan JY, Yacharoen S, Zhang M. 2013 - Families of Dothideomycetes. Fungal Diversity 63 (1): 1313. doi:10.1007/s13225-013-0263-4

Shearer CA, Raja HA, Miller AN, Nelson P, Tanaka K, Hirayama K, Marvanova L, Hyde KD, Zhang Y. 2009 - The molecular phylogeny of freshwater Dothideomycetes. Stud Mycol 64, $145-153$

Suetrong S, Boonyeun N, Pang KL, Ueapattanakit J, Klaysuban A, Sri-Indrasutdhi V, Sivichai S, Jones EBG. 2011 - A taxonomic revision and phylogenetic reconstruction of the Jahnulales (Dothideomycetes), and the new family Manglicolaceae. Fungal Diversity 51, 163-188. doi:10.1007/s13225-011-0138-5

Suetrong S, Rungjindamai N, Sommai S, Rungareerate P, Sommrithipol S, Jone EBG. 2014 Wiesneriomyces a new lineage of Dothideomycetes (Ascomycota) basal to Tubeufiales. Phytotaxa 176, 283-297. doi:10.11646/phytotaxa.176.1.27.

Tubaki K. 1958 - Studies on the Japanese hyphomycetes V. Leaf and stem group with a discussion of the classification of hyphomycetes and their perfect stages. J. Hattori bot. Lab. 20, 142244.

White TJ, Bruns T, Lee S, Taylor J. 1990 - Amplification and direct sequencing of fungal ribosomal RNA genes for phylogenetics. In: Innis, MA, Gelfand DH, Sninsky JJ, White TJ. (Eds.) PCR Protocols: a guide to methods and applications. Academic Press, New York, USA, pp. 315-322.

Wijayawardene NN, Crous PW, Kirk PM, Hawksworth DL, Boonmee S, Braun U, Dai DQ, D'Souza MJ, Diederich P, Dissanayake A, Doilom M, Hongsanan S, Jones EBG, Groenewald JZ, Jayawardena R, Lawrey JD, Liu JK, Lücking R, Madrid H, Manamgoda DS, Muggia L, Nelsen MP, Phookamsak R, Suetrong S, Tanaka K, Thambugala KM, Wanasinghe DN, Wikee S, Zhang Y, Aptroot A, Ariyawansa HA, Bahkali AH, Bhat DJ, Gueidan C, Chomnunti P, Hoog GSD, Knudsen K, Li WJ, Mckenzie EHC, Miller AN, Phillips AJL, Piątek M, Raja HA, Shivas RS, Slippers B, Taylor JE, Tian Q, Wang Y, Woudenberg JHC, Cai L, Jaklitsch WM, Hyde KD. 2014 - Naming and outline of dothideomycetes - 2014: including proposals for the protection or suppression of generic names. Fungal Diversity 69(1), 1-55.

www.indexfungorum.org/names/Names.asp 